\title{
Biosynthesis of the Allylphenols Eugenol and Methyleugenol in Ocymum basilicum $\mathrm{L}$.
}

\author{
By M. Klischies,* J. Stöckigt, and M. H. ZENK \\ (Lehrstwhl für Pflanzenphysiologie der Ruhr-Universität Bochum, D 463 Bochun, W. Germany)
}

Summary The allylphenols eugenol and methyleugenol are synthesized in $O$. basilicum from ferulic acid and coniferyl alcohol whose sidechains are converted into allyl groups with retention of all carbon atoms, and hydrogen atoms of the hydroxy-group are quantitatively incorporated into the allyl group; a previous hypothesis for the biosynthesis of these compounds, which involved loss of the C-1 from these precursors, has therefore to be rejected.

ON the basis of comparative phytochemical considerations it can be assumed that allyl- and propenyl-phenols in higher plants originate from the cinnamate carbon skeleton.1,2 The most likely intermediates are substituted cinnamyl aldehydes and cinnamyl alcohols. However, recent studies on the biosynthesis of eugenol in Ocimum basilicum led Canonica et al. $^{3}$ to reject this possibility. They fed D,Lphenylalanine, labelled with ${ }^{14} \mathrm{C}$ in different positions of the side chain mixed with non-specifically tritiated L-phenylalanine and observed in the case of $\left[1-{ }^{14} \mathrm{C}\right]$ phenylalanine an increase in the ${ }^{3} \mathrm{H}:{ }^{14} \mathrm{C}$ ratio of the isolated eugenol. This was interpreted as being due to loss of the carboxyl group of phenylalanine at the cinnamate stage. Feeding experiments with $\mathrm{L}-\left[\mathrm{Me}^{14} \mathrm{C}\right]$ methionine showed an incorporation of the labelled atom into the allylphenols and it was ${ }^{3,4}$ proposed that the terminal carbon atom may be derived from this precursor. Biosynthetically prepared $U$-tritiated ferulic acid was also found to be incorporated into the allylphenols. The above observations, that eugenol is derived from L-phenylalanine via oxygenated cinnamic acids with loss of the carboxy-group and incorporation of an 'extra' carbon atom into the side-chain, have been recently confirmed." It is clear, however, that further work is required to clarify this situation. ${ }^{5}$

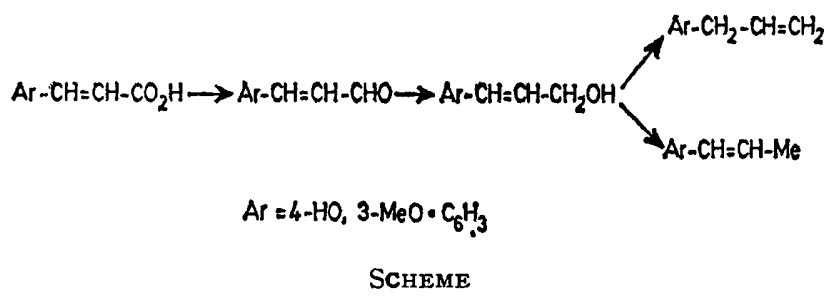

We report that the above observations are incorrect in that allylphenols are formed from the intact carbon skeleton of ring-substituted cinnamic acids and their derivatives, as loss of the carboxy-group of ferulic acid, incorporation of an 'extra' carbon atom, and removal of the hydrogen atoms from C-l of coniferyl alcohol did not occur during the biosynthesis of eugenol and methyleugenol.

A high-eugenol-yielding $O$. basilicum strain 'Genovese' (Ingegnoli, Milan, Italy) was used for these experiments. Glucoferulic acid was synthesized by a Knoevenagel reaction of $\left[1-{ }^{14} \mathrm{C}\right]$ malonic acid with acetylated $\left[\mathrm{O}-\mathrm{CH}_{2}{ }^{3} \mathrm{H}\right]$ glucovanillin. ${ }^{\circ}$ Thus the labelled ferulic acid unit contained ${ }^{14} \mathrm{C}$ and ${ }^{3} \mathrm{H}$ within the same molecular species. $\left[{ }^{14} \mathrm{C} ;{ }^{3} \mathrm{H}\right]-$ Coniferin was synthesized by standard procedure from the above glucoferulic acid. $\left[\gamma^{-14} \mathrm{C}^{3} \mathrm{H}_{2} \mathrm{OH}\right]$ Coniferin was syn- 
TABLE. Incorporation of potential precursors into allylphenols.

\begin{tabular}{|c|c|c|c|c|c|c|c|}
\hline \multirow[b]{2}{*}{ Precursor ${ }^{\mathrm{B}}$} & \multicolumn{3}{|c|}{ Precursor } & \multicolumn{2}{|c|}{ Eugenol } & \multicolumn{2}{|c|}{ Methyleugenol } \\
\hline & $\begin{array}{l}\text { Amount } \\
\text { taken up } \\
(\mu \mathrm{mol})\end{array}$ & $\begin{array}{l}\text { Spec. Act. } \\
\text { d.p.m. }{ }^{3} \mathrm{H} ;{ }^{14} \mathrm{C} \\
\times 10^{6} / \mu \mathrm{mol}\end{array}$ & ${ }^{3} \mathrm{H}:{ }^{14} \mathrm{C}$ & $\begin{array}{c}\text { Incorp. } \\
(\%)\end{array}$ & ${ }^{8} \mathrm{H}:{ }^{14} \mathrm{C}$ & $\underset{(\%)}{\text { Incorp. }}$ & ${ }^{3} \mathrm{H}:{ }^{14} \mathrm{C}$ \\
\hline $\begin{array}{c}\text { Glucoferulic acid } \\
{\left[\gamma-{ }^{14} \mathrm{CO}_{2} \mathrm{H} ;-\mathrm{O}-\mathrm{CH}_{2}{ }^{3} \mathrm{H}\right]}\end{array}$ & $1 \cdot 27$ & $21 \cdot 89 ; 2 \cdot 15$ & $10 \cdot 18: 1$ & 0.155 & $10 \cdot 3: 1^{b}$ & $0 \cdot 04$ & $9 \cdot 2: 1$ \\
\hline $\begin{array}{l}\text { Glucoconiferyl alcohol } \\
{\left[-\gamma^{14} \mathrm{CH}_{2} \mathrm{OH} ;-\mathrm{O}-\mathrm{CH}_{2}{ }^{3} \mathrm{H}\right]} \\
{\left[-\gamma^{14} \mathrm{C}^{3} \mathrm{H}_{2} \mathrm{OH}\right]}\end{array}$ & $\begin{array}{l}1.00 \\
0.54\end{array}$ & $\begin{array}{l}24.90 ; 2.20 \\
18 \cdot 67 ; 1.73\end{array}$ & $\begin{array}{l}11 \cdot 31: 1 \\
10 \cdot 79: 1\end{array}$ & $\begin{array}{l}0.012 \\
0.016\end{array}$ & $\begin{array}{c}9 \cdot 22: 1 \\
10 \cdot 87: 1^{c}\end{array}$ & 0.015 & $11 \cdot 77: 1$ \\
\hline
\end{tabular}

a The precursors were fed through the cut ends of two $O$. basilicum plants (11 g per plant). After $2 \mathrm{~h}$ the plants were steam distilled. The allylphenols were isolated and purified as previously reported.3,4 Their identity and purity was checked by radio g.l.c. and m.s. On an average, $16 \mu \mathrm{mol}$ of eugenol and $54 \mu \mathrm{mol}$ of methyleugenol was isolated. b Average of 4 independent feeding experiments. c Average of 5 independent feeding experiments.

thesized by reduction of acetylated $\left[\gamma^{-14} \mathrm{COCl}\right]$ glucoferuloyl chloride with $\mathrm{LiB}^{3} \mathrm{H}_{4}{ }^{7}$ Tritium was exclusively located in the alcohol group of coniferin, as $53 \%$ (calc. $50 \%$ ) of tritium was lost when coniferyl alcohol liberated by the action of $\beta$-glucosidase from coniferin was enzymatically converted into coniferyl aldehyde by means of specific cinnamyl alcohol dehydrogenase $[\mathrm{NADP}] ;^{8}$ the same results were obtained when $\left[\gamma^{-14} \mathrm{C}^{3} \mathrm{H}_{2} \mathrm{OH}\right]$ coniferin was oxidised with $\mathrm{MnO}_{2}$ to give the corresponding aldehyde. Glucoderivatives were used in feeding experiments because they are more stable and soluble compared to the free phenols. The glucose part of the precursors is believed to split off during the passage through the plasmalemma of the plant cells. Experiments using the three differently labelled precursors showed that in all cases incorporation of radioactivity into the allylphenol derivatives eugenol and methyleugenol of $O$. basilicum occurred (Table).

A comparison of the ${ }^{3} \mathrm{H}:{ }^{14} \mathrm{C}$ ratio of precursor and product clearly shows that there is no change in this ratio and therefore no loss of the C-I atom of the sidechain during the in vivo conversion, as has been suggested earlier.,4 Unequivocal degradation ${ }^{9}$ of the terminal carbon atom of both allylphenols from a ferulic acid feeding experiment demonstrated that ca. $97 \%$ of the ${ }^{14} \mathrm{C}$-label was located in this terminal position, corresponding to C-l of the precursors, since the resulting homoveratrum aldehyde contained only tritium and was devoid of ${ }^{14} \mathrm{C}$-activity. Of considerable interest is the fact that $\left[\gamma^{-14} \mathrm{C}^{3} \mathrm{H}_{2} \mathrm{OH}\right]$ coniferin is incorporated into eugenol without change of the ${ }^{3} \mathrm{H}:{ }^{14} \mathrm{C}$ ratio. This demonstrates that both hydrogen atoms, linked directly to $\mathrm{C}-1$ of the cinnamyl alcohol, are retained during the reduction to allylphenols and proves that these alcohols are immediate precursors in this conversion.

These experiments show that allyl- and propenyl-phenol ${ }^{10}$ derivatives of higher plants have common precursors and are biosynthesized as shown in the Scheme. The exact mechanism by which cinnamyl alcohol derivatives are reduced to allyl- or propenyl-phenols has still to be investigated.

This investigation was supported by the Deutsche Forschungsgemeinschaft, Bonn-Bad Godesberg.

(Received, 11th August 1975; Com. 921.)

1 A. J. Birch, 'Chemical Plant Taxonomy', ed. T. Swain, Academic Press, London, 1963, pp. 141-148.

2 T. A. Geissman and D. H. G. Crout, 'Organic Chemistry of Secondary Plant Metabolism', Freeman-Cooper, San Francisco, 1969, pp. $150-152$.

3 L. Canonica, P. Manitto, D. Monti, and M. Sanchez A., Chem. Comm., 1971, 1108.

4 P. Manitto, D. Monti, and P. Gramatica, J.C.S. Perkin I, 1974, 1727.

5 E. Haslam, 'The Shikimate Pathway', Butterworths, London, 1974, pp. 217-218.

B J. Stöckigt, unpublished results.

7 R. H. Cornforth, Tetrahedron Letters, 1974, 3933.

${ }^{8}$ R. L. Mansell, G. G. Gross, J. Stöckigt, H. Franke, and M. H. Zenk, Phytochemistry, 1974, 13, 2427.

N. Walker, J. McKinney, and E. Oswald, J. Labelled Compounds, 1974, 10, 405.

10 P. Manitto, D. Monti, and P. Gramatica, Tetrahedron Letters, 1974, 1567. 